\title{
Water-Level Fluctuations of Urmia Lake: Relationship with the Long-Term Changes of Meteorological Variables (Solutions for Water-Crisis Management in Urmia Lake Basin)
}

\author{
Mojtaba Zoljoodi' ${ }^{1}$ Ali Didevaras $2^{2}$ \\ ${ }^{1}$ Iranian National Institute for Oceanography and Atmospheric Science, Tehran, Iran \\ ${ }^{2}$ Atmospheric Sciences and Meteorological Research Center, Tehran, Iran \\ Email: alididehvar714@yahoo.com
}

Received 23 April 2014; revised 20 May 2014; accepted 16 June 2014

Copyright (C) 2014 by authors and Scientific Research Publishing Inc. This work is licensed under the Creative Commons Attribution International License (CC BY). http://creativecommons.org/licenses/by/4.0/

\section{(c) (7) Open Access}

\begin{abstract}
Urmia Lake in northwest of Iran, through the recent years has been extremely faced with the water crisis. Climate variations and anthropogenic impacts could be two main affiliated factors in this regard. We considered the long term data series of precipitation, temperature and evaporation in monthly and yearly scales in order to compare to water-level values of Urmia Lake. The statistics approaches such as: standard deviation, trend analysis, $T$ test, Pearson and Spearman correlations, liner regression are used to analyze all variables. The results released that the water-level of Urmia Lake along with the precipitation and temperature of the lake's basin have experienced the periodic changes through 1961 to 2010 , as there are some gradual dryness trends on the study area according to precipitation and temperature variations. Urmia Lake periodic water-level fluctuations show more significant correlation to temperature than the precipitation. Whiles, the water-level's decreasing behavior especially through 1998 to 2010 is more harsh and different than the rate that is considered for precipitation's decrease and temperature's increase. Thus, there could be some anthropogenic factors in the basin which produced some supplementary causes to shrink Urmia Lake. Extracting the double precipitation over the basin through introducing and categorizing of atmospheric synoptic systems in order to cloud seeding operation could be one of urgent and innovative solutions to mitigate water crisis in the basin.
\end{abstract}

\footnotetext{
${ }^{*}$ Corresponding author.
} 


\section{Keywords}

\section{Urmia Lake, Water-Level Fluctuation, Climate Variations, Water Crisis, Anthropogenic Impacts, Cloud Seeding Operation}

\section{Introduction}

Urmia Lake is a hyper-saline lake in northwestern Iran near Iran's border with Turkey. The lake is between the Iranian provinces of East Azerbaijan and West Azerbaijan. It is the largest lake in the Middle East and the third largest saline lake on earth [1], with a surface area of approximately $5200 \mathrm{~km}^{2}$ (2000 mile $), 140 \mathrm{~km}(87 \mathrm{mi})$ length, $55 \mathrm{~km}$ (34 mi) width, and $16 \mathrm{~m}$ (52 ft) depth

Especially during the recent years Urmia Lake extremely has been shrunk and its water-level has illustrated negative trends, as these conditions damaged considerably the ecosystems, environment and socio-economic activities of the local communities, within and around this lake [2]. Periodic changes in climatic and hydrologic variables that cause wide climate changes as well as droughts worldwide and in Iran seem to have a crucial impact in water crisis of Urmia Lake (Figure 1 and Figure 2).
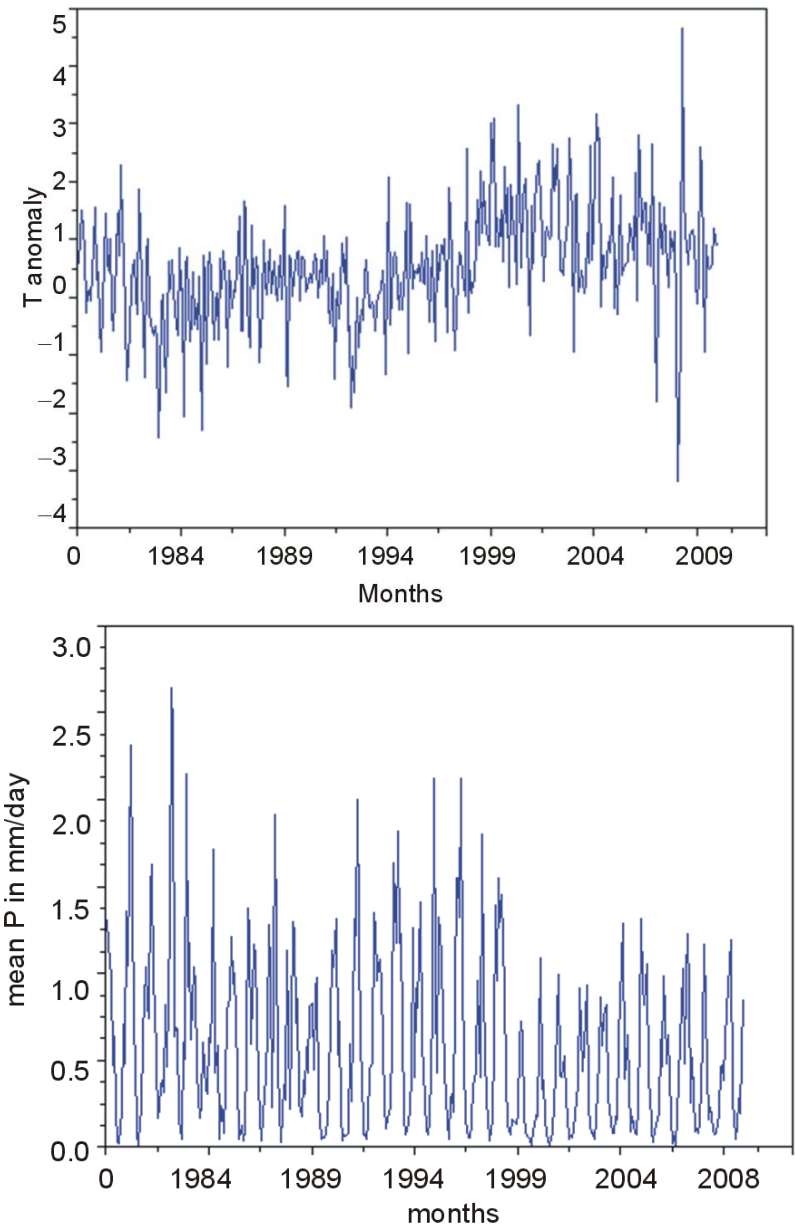

Figure 1. Monthly values of temperature anomaly (top) and precipitation amount (bottom) in northwest of Iran during 1980-2010 (source; NOAA $^{1}$ ). Note: increase of temperature and decrease of precipitation through 2000-2010.

${ }^{1}$ National Oceanography and Atmospheric Administration. 


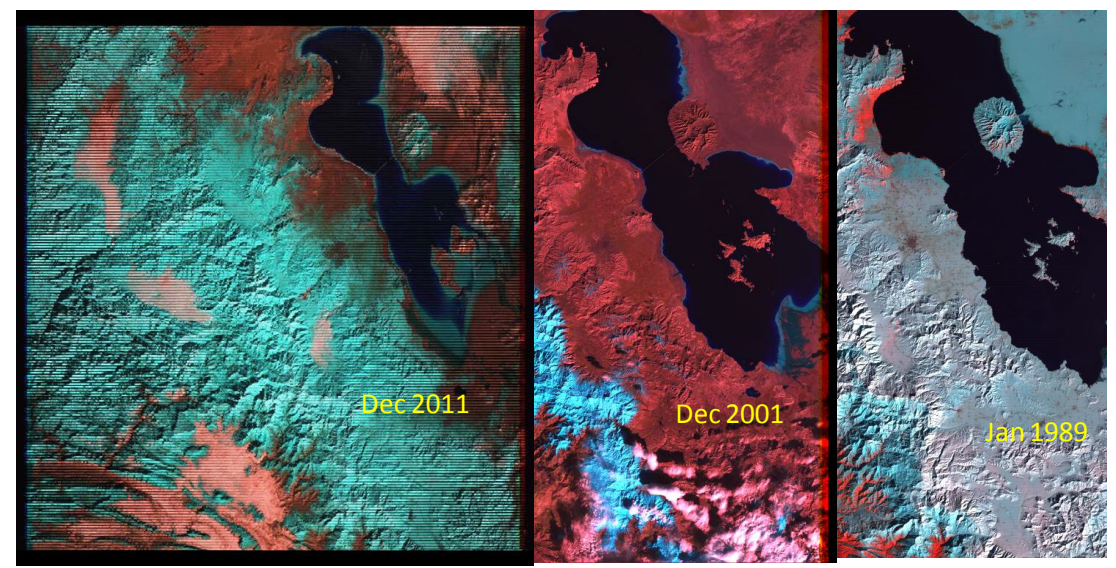

Figure 2. Satellite images of Urmia Lake in 1989 (right), 2001 (center) and 2011 (left): these images obviously show the negative trend of water-level and gradually shrinking of the lake through 22 years (source: U.S. Geological Survey).

Some researchers have illustrated this fact that the water-level of Urmia Lake consistently have been changing through historical periods, although there is not any agreement between the researchers about the trend and intensity of these changes. As an example, Jabbarlu-Shabestary in 2000 [3] through a research has found that in 5 10 thousand years ago water-level of the lake fell down more than the current position. The results derived from a paleoclimatic investigation on the lake bed by Ali mohammadi et al., 2011 [4] indicated that the lake had never been dried through 23 - 40 thousand years ago, whereas all investigations and data series confirm seasonal and periodic fluctuations in the lake's water-level.

Figure 3 shows the yearly changes of the lake's water-level in a 45-year period (1966-2010). From 1998 extremely water-level of Urmia Lake has been decreased below its long-term normal level (1275.35 m).

Maximum depth of the lake measured about $16 \mathrm{~m}$, and it's water-level is based on the mean sea level (MSL) varies between $1272 \mathrm{~m}-1278 \mathrm{~m}$ [5].

If the height of $1274.1 \mathrm{~m}$ for Urmia Lake's water-level considered the crisis threshold, the surface area of the lake should be about $5700 \mathrm{~km}^{2}$ [6], whereas, currently the lake is shrunk up to a surface almost $3000 \mathrm{~km}^{2}$ [7].

Satellite images analysis in order to derive the shore line's changing illustrated a wide range of seasonal/periodic variations in the surface of the lake during the recent decade. Maximum changes happened because of decreasing the lake's water-level up to $3.5 \mathrm{~m}$ from normal, and then resulted in basic shifts over shore lines in particularly on the southeastern and eastern coasts. Appearance of such significant water-level fluctuations caused the shrinking of Urmia Lake up to $23 \%$, so the environmental feedbacks of these critical conditions threat seriously the valuable ecosystems of the lake [8].

Different investigations indicate relative dependency between ecological status of lakes and climatologic changes. As an example, Kebede, S., et al. in 2006 [9] found around 20\% changes in climatologic variables over Tana Lake basin through a 50-year period, although water-level of the lake has been remained stable. In the case of Aral Lake the climate effect is estimated about $14 \%$ versus $86 \%$ of man-made impact on water-level variations [10] [11]. The studies by Lofgren et al. (2002) [12], through a hydrological modeling suite using input data from the CGCM1(The first version of the Canadian Global Coupled Model) predict large drops in lake levels, up to a maximum of $1.38 \mathrm{~m}$ on Lakes Michigan and Huron by 2090 .

A developed research by Tabari and Ghalehni, 2012 [13], on water-need of Urmia lake shows an extreme increasing trend in water-need of this lake due to recent droughts. It is notable that the water influx to Urmia Lake in the recent years decreased considerably up to $77 \%$, so this critical condition of the lake doesn't seem to happen only by climatic effects, regarding the fact that the wide constructive operations and developmental projects are in performance over the Urmia Lake basin.

\section{Study Area}

Urmia Lake, located in northwestern of Iran in a geographic position between $45^{\circ} \mathrm{E}-46^{\circ} \mathrm{E}$ and $37^{\circ} 4^{\prime} \mathrm{N}-38^{\circ} 17^{\prime} \mathrm{N}$, is an oligotrophic lake of thalassohaline origin with a total surface area between 4750 and $6100 \mathrm{~km}^{2}$ and a maximum depth of $16 \mathrm{~m}$ at an altitude of $1250 \mathrm{~m}$ [14]-[16] (Figure 4). 


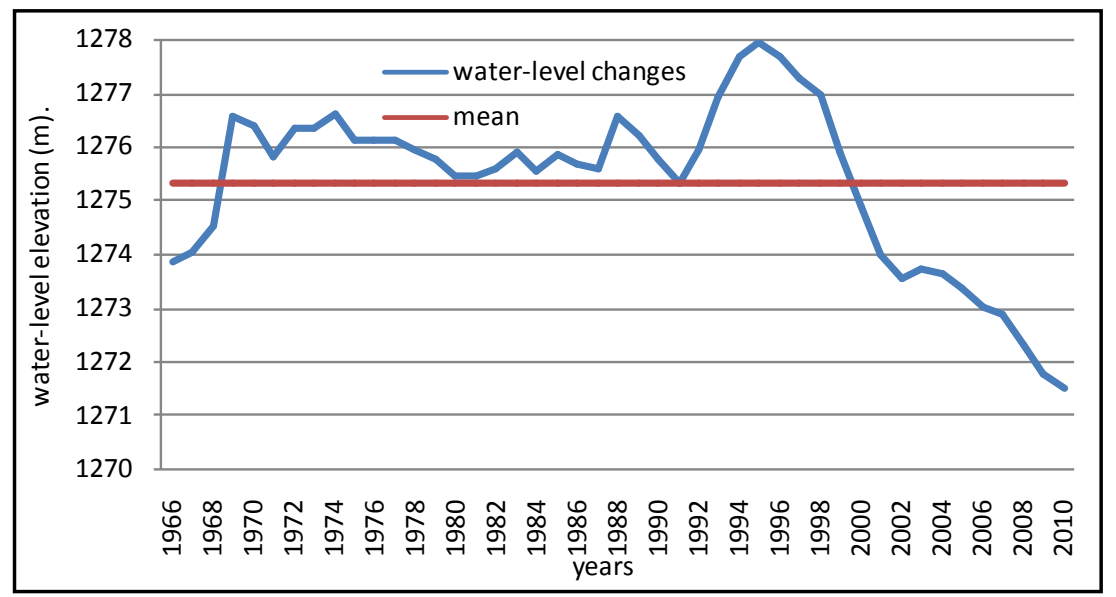

Figure 3. Water-level fluctuations of Urmia Lake during 1966-2010 (based on height from mean sea level, in meter).

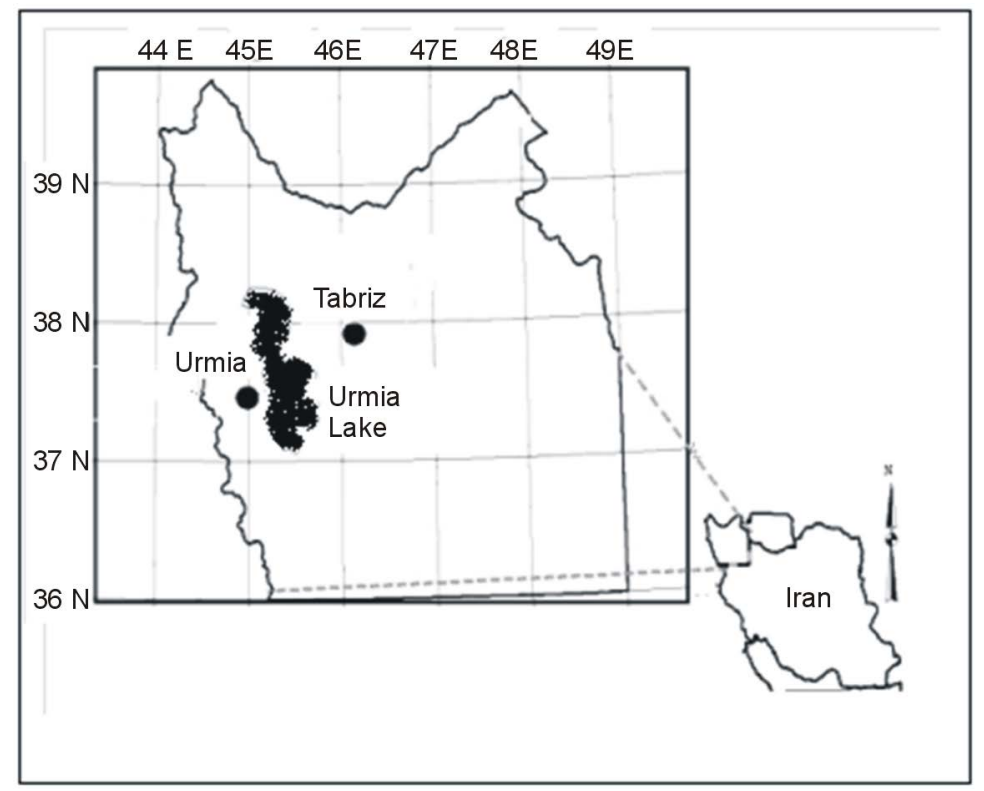

Figure 4. Geographic position of Urmia Lake in northwest of Iran.

The total catchment area of the lake is about $51,876 \mathrm{Km}^{2}$ which is $3.15 \%$ of that of the entire country, and includes $7 \%$ of the total surface water in Iran. There are thirteen main rivers in the lake basin, among them Zarrineh rood, the largest with a total annual discharge value of about $2 \times 109 \mathrm{~m}^{3}$ [17] [18]. Climate in the Urmia Lake basin is harsh and continental, affected mainly by the mountains surrounding the lake [17] [19]. Considerable seasonal fluctuations in air temperature occur in this semi arid climate with an annual average precipitation of between 200 and $300 \mathrm{~mm}$ [20]. The air temperature usually ranges between $0^{\circ} \mathrm{C}$ and $-20^{\circ} \mathrm{C}$ in winter and up to $40^{\circ} \mathrm{C}$ in summer. From this point of view, Urmia Lake is a critical asset for the region, because it acts to moderate these extremes [21]. Annual inflow into the lake is $6900 \times 106 \mathrm{~m}^{3}$, of which $4900 \times 106 \mathrm{~m}^{3}$ is from rivers, $500 \times 106 \mathrm{~m}^{3}$ from flood water (through rainfall) and $1500 \times 106 \mathrm{~m}^{3}$ from precipitation [22]. Underground springs are also a source of water, but the volume is not known [23].

\section{Material and Methods}

Firstly, all synoptic stations on the Urmia Lake basin and surrounding areas, have been taken in consideration, then we selected four stations, which provide long-term data series (50-year data availability) and fully cover the 
basin, including Tabriz in east, Saghez in south, Urmia and Khoy respectively in west and northwest of the basin (Table 1). The meteorological variables including precipitation, temperature and evaporation through the aforementioned stations have been provided. Precipitation and temperature monthly data series were available over 1961 to 2010, but for evaporation data series; the longest available period covers only from 1990 to 2010.

The water-level monthly data series of Urmia Lake also during a 45-year period from 1966 to 2010 have been obtained through the regional water resource administration of West Azerbaijan province.

In the next step, a data bank in SPSS and Excel software has been designed. We refined all data series and then arranged them in monthly and yearly scales.

In order to find the amount and severity of yearly and monthly changes in the variables and setting those in a comparable frame, all data series have been standardized via the relation below:

1) Standardizing equation:

$$
z=\frac{x-\mu}{\sigma}
$$

where: $x=$ the variables, $\mu=$ a long-term average, $\sigma=$ standard deviation.

2) Average:

$$
\mu=\frac{\Sigma x}{N}
$$

where: $N=$ number of the variables.

3) Standard deviation:

$$
\sigma=\sqrt{\frac{\sum(x-\mu)^{2}}{N}}
$$

Then, trend test and standard deviation analysis have been applied, also to compare the periodic changes of all data series we applied T test. Additionally, Correlation and linear regression analysis have been used to estimate the compatibility between all hydro-meteorological variables.

\section{Results}

1) Trend test and standard deviation analysis:

To estimate the severity of long term changes of all variables, firstly in each four selected stations the Trend analysis to the data series during a long period has been applied. All four stations illustrated rising trends for temperature and decreasing trends for the precipitation, whereas Tabriz synoptic station in the eastern part of basin shows more extreme trends than the 3 further stations of the study area. As in Tabriz station the decreasing trend of precipitation is estimated about -69 , along with the growing trends of temperature and evaporation respectively +0.92 and +0.8 . The standard deviation analysis in all selected stations confirms the existence of high temporal variability for precipitation comparing to temperature. The Percent of normal of standard deviations, confirms more harsh fluctuations for precipitation, which could potentially imply the effective role of precipitation's departure from normal in happening of severe droughts over the study area. Urmia Lake's water-level also indicates a falling trend around -0.76 , with a standard deviation of $30 \%$.

Basically, based on the outputs of the trend test and standard deviation analysis, climatic dryness over the basin has been expanded, so these conditions could influence water inflow to the lake as well as water level of the lake through direct evaporation (Table 2).

Table 1. Position of the selected stations on the study area (Urmia basin).

\begin{tabular}{cccc}
\hline Stations & Elevation (in meter) & Longitude & Latitude \\
Tabriz & 1361 & $46^{\circ} 17^{\prime}$ & $38^{\circ} 05^{\prime}$ \\
Urmia & 1315.9 & $45^{\circ} 5^{\prime}$ & $37^{\circ} 32^{\prime}$ \\
Saghez & 1522.8 & $46^{\circ} 16^{\prime}$ & $36^{\circ} 15^{\prime}$ \\
Khoy & 1103 & $44^{\circ} 58^{\prime}$ & $38^{\circ} 33^{\prime}$ \\
\hline
\end{tabular}


Table 2. The results derived through trend and standard deviation analyzes in four selected stations on Urmia Lake basin.

\begin{tabular}{ccccccc}
\hline Stations & $\begin{array}{c}\text { Precipitation } \\
\text { Trend }\end{array}$ & $\begin{array}{c}\text { Precipitation } \\
\text { Stdv. } \%\end{array}$ & $\begin{array}{c}\text { Temperature } \\
\text { Trend }\end{array}$ & $\begin{array}{c}\text { Temperature } \\
\text { Stdv. } \%\end{array}$ & $\begin{array}{c}\text { Evaporation } \\
\text { Trend }\end{array}$ & $\begin{array}{c}\text { Evaporation } \\
\text { Stdv. \% }\end{array}$ \\
\hline Tabriz & -0.69 & $30 \%$ & +0.92 & $7.5 \%$ & +0.8 & $9.5 \%$ \\
Urmia & -0.12 & $31.6 \%$ & +0.07 & $9 \%$ & +0.12 & $8 \%$ \\
Saghez & -0.32 & $28.76 \%$ & +0.28 & $11.8 \%$ & +0.3 & $18.4 \%$ \\
Khoy & -0.38 & $28 \%$ & +0.48 & $9.8 \%$ & +0.4 & $9.8 \%$ \\
\hline
\end{tabular}

2) Monthly and yearly changes of the hydro-meteorological variables:

Monthly trend analysis on all variables indicates some notable results, as monthly decreasing trends of precipitation along with rising trends of temperature and evaporation are evident for majority of months; the water-level of Urmia Lake in all months of year shows persistent negative trends. The severity of precipitation-fall and rising of temperature as well as evaporation over Jan to Jun is considered more than what is found for Jul to Dec, on the contrary, decreasing trend of water-level over Jul to Dec shows more severity (Figure 5). Thus we did not find a seasonal correspondence between meteorological indicators over the basin and water-level variations of the Lake.

Yearly standardized values of precipitation, temperature and water-level of Urmia Lake through 1966 to 2010 , illustrate a more fluctuant behavior for the meteorological factors (temperature and precipitation) than the water-level. From 1995 water-level indicates a steady decreasing trend, as through 1998-2010 it goes extremely below normal. Also, from 1995 to 2010 temperature is raised above normal and precipitation shows a decreasing behavior, so their peak is found over 1996 to 2002, although their intensities are significantly weak by comparing to the falling rate of water-level of Urmia Lake, and both of those (temperature and precipitation) vary almost around normal especially through 2002 to 2010 (Figure 6).

Regarding the results, it is notable that the water-level of Lake in particular from 1998 to 2010 through all months of year has been slumped harshly and unnaturally, while precipitation and temperature released comparatively more different and poor changes.

3) Comparison of periodic changes in precipitation, temperature and water-level of Urmia Lake:

In order to understand the rate and modality of periodic changes of the variables a $\mathrm{T}$ test analysis has been applied, as the entire study period is divided into three spells for comparing them. About precipitation, by comparing the mean value of the recent 16-year spell (1994 to 2009) to the first one (1961 to 1976) we found precipitation declines on the basin around $76 \mathrm{~mm}$, so precipitation's mean value on the basin from $336 \mathrm{~mm}$ in 1961-1976, decreased to $273 \mathrm{~mm}$ in 1977-1993 and $260 \mathrm{~mm}$ in 1994-2009 (Table 3). Temperature also shows a significant increasing trend on the basin, as in total we have found around $1.39^{\circ} \mathrm{C}$ grow in temperature's mean by comparing the recent 16-year period (1994 to 2009) to 1961-1976. Mean value of temperature in $1961-1976$ was $12^{\circ} \mathrm{C}$ that is reached $12.45^{\circ} \mathrm{C}$ in $1977-1993$ and $13.39^{\circ} \mathrm{C}$ in the recent spell of $1994-2009$ (Table 4).

The standard deviations and standard mean errors of precipitation and temperature data series during the 3 mentioned spells gradually are declining along with the variations of mean values, and illustrating the persistency and extremity of the dryness on the basin especially over the recent 16-year spell, by low positive and negative fluctuations parallel to a falling behavior of precipitation and an increasing behavior of temperature (Table 3 and Table 4).

T test analysis on water-level of Urmia Lake released a decrease around 2 m through 1996 to 2010 comparing to the previous spell (1981-1995). The water-level of Urmia Lake based on the mean sea level, through 1966 to 1980 averagely was around $1275.7 \mathrm{~m}$, and then it is increased to $1276.14 \mathrm{~m}$ in 1981-1995, whiles it is decreased extremely to $1274.17 \mathrm{~m}$ in 1996-2010. Although standard deviations and standard mean errors significantly indicated a rising trends which could imply the persistent slumping of the lake's water level through 1996 to 2010 , as the water level of the lake from $1278 \mathrm{~m}$ in 1996 reached $1271.5 \mathrm{~m}$ in 2010 (Table 5).

4) Correlation and liner regression analyze between water-level of Urmia Lake with temperature and precipitation data series:

To find the relationship between the changes of meteorological variables and the water-level fluctuations of Urmia Lake during a long period (1966 to 2010), we applied the Spearman (nonparametric) and the Pearson (parametric) correlation analyzes. Both correlation methods (Spearman and Pearson) released a significant relationship for a combination of water-level (3-year moving average) and temperature by a correlation rank about 
-0.5 , whiles the combination of precipitation and water-level shows poor correlation ranks (in max 0.18) (Table 6). Regression analysis also confirmed significant relationship for 3-year accumulated water-level values and temperature, with a $\mathrm{R}^{2}$ rank of 0.22 (Table 7 and Figure 7). Thus these results may imply a more significant periodic impact of temperature to water-level variations of the lake comparing to precipitation.

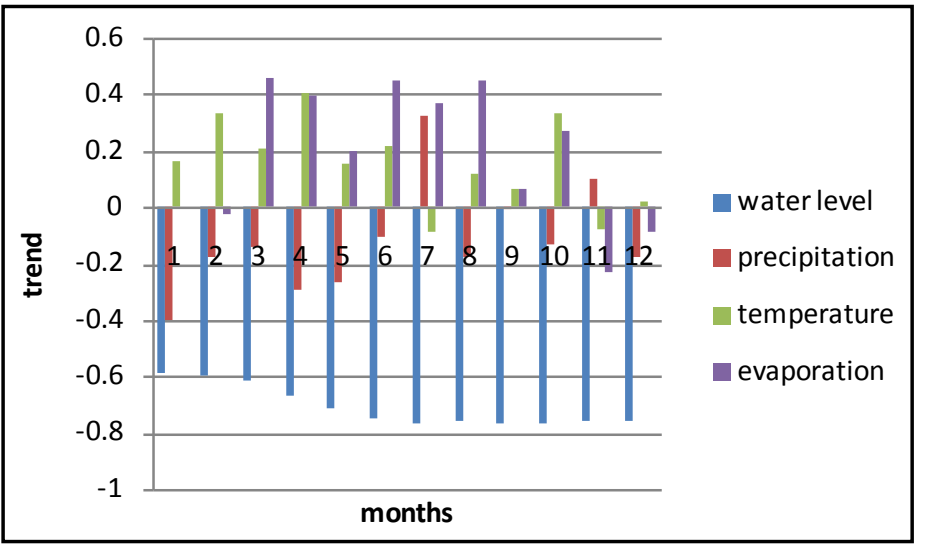

Figure 5. Monthly trend analysis on precipitation, temperature, evaporation and water-level during a long-term period.

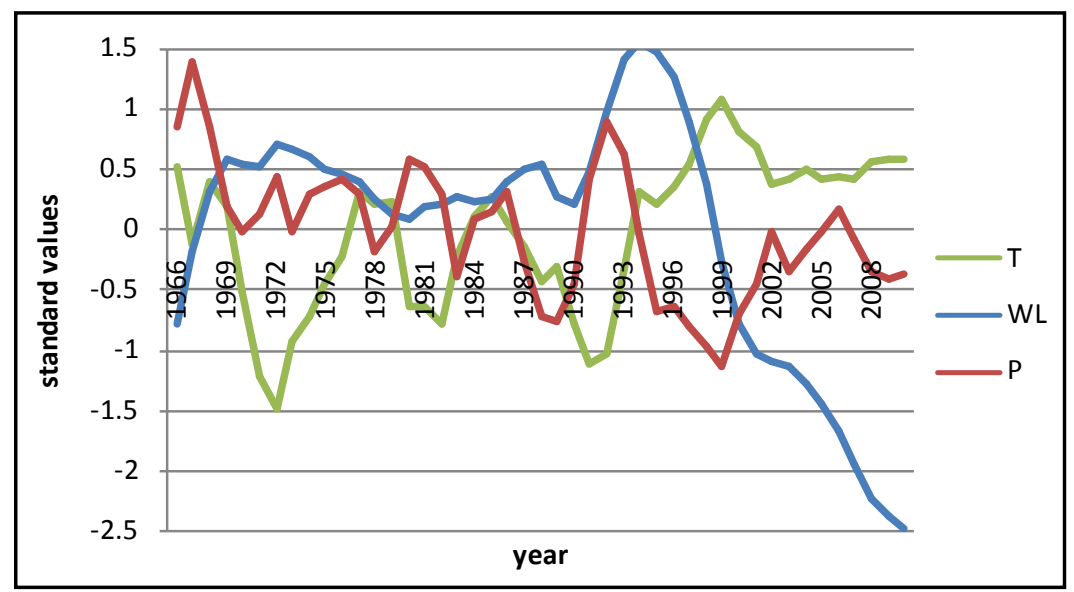

Figure 6. Comparing the yearly changes of precipitation, temperature and waterlevel of Urmia Lake during 1966 to 2010.

Table 3. The results derived through T test on precipitation data series of the watershed in three 16-year spells (through 1961 to 2009).

\begin{tabular}{ccccccc}
\hline Periods & $\mathrm{N}$ & Mean & Std. Deviation & $\begin{array}{c}\text { Std. Error } \\
\text { Mean }\end{array}$ & \\
\hline $\mathbf{1 9 6 1 - 1 9 7 6}$ & 16 & $3.3692 \mathrm{E} 2$ & $\mathbf{9 5 . 3 6 5 7 8}$ & $\mathbf{2 3 . 8 4 1 4 5}$ & \\
$\mathbf{1 9 7 7 - 1 9 9 3}$ & 16 & $2.7376 \mathrm{E} 2$ & $\mathbf{7 7 . 7 9 1 3 9}$ & $\mathbf{1 9 . 4 4 7 8 5}$ & \\
$\mathbf{1 9 9 4 - 2 0 0 9}$ & 16 & $2.6030 \mathrm{E} 2$ & $\mathbf{7 1 . 2 0 2 1 9}$ & $\mathbf{1 7 . 8 0 0 5 5}$ & & \\
\hline Periods & $\mathrm{t}$ & df & Sig. (2-tailed) & $\begin{array}{c}\text { Mean } \\
\text { Difference }\end{array}$ & 95\% Confidence Interval of the Difference \\
\hline $\mathbf{1 9 6 1 - 1 9 7 6}$ & 14.132 & 15 & 0 & $\mathbf{3 7 4 . 9 2 5}$ & 334.1082 & Uper \\
$\mathbf{1 9 7 7 - 1 9 9 3}$ & 15.379 & 15 & 0 & $\mathbf{3 5 0 . 7 6 2 5}$ & 313.8215 & 387.7418 \\
$\mathbf{1 9 9 4 - 2 0 0 9}$ & 13.385 & 15 & 0 & $\mathbf{3 2 5 . 3}$ & 294.8479 & 356.7521 \\
\hline
\end{tabular}


Table 4. The results derived through T test on temperature data series of the watershed in three 16-year spells (through 1961 to 2009).

\begin{tabular}{cccccc}
\hline Periods & $\mathrm{N}$ & Mean & Std. Deviation & $\begin{array}{c}\text { Std. Error } \\
\text { Mean }\end{array}$ & \\
\hline $\mathbf{1 9 6 1 - 1 9 7 6}$ & 16 & 12.0267 & $\mathbf{0 . 9 2 4 2 1}$ & $\mathbf{0 . 2 3 1 0 5}$ & $\mathbf{0 . 1 7 7 3 3}$ \\
$\mathbf{1 9 7 7 - 1 9 9 3}$ & 16 & 12.4541 & $\mathbf{0 . 7 0 9 3 3}$ & $\mathbf{0 . 1 7 4 4 2}$ & 95\% Confidence Interval of the Difference \\
$\mathbf{1 9 9 4 - 2 0 0 9}$ & 16 & 13.3933 & $\mathbf{0 . 6 9 7 6 8}$ & Mean & Lower \\
\hline Periods & $\mathrm{t}$ & $\mathrm{df}$ & Sig. (2-tailed) & Difference & 11.5342 \\
\hline $\mathbf{1 9 6 1 - 1 9 7 6}$ & 52.052 & 15 & 0 & $\mathbf{1 2 . 0 2 6 6 9}$ & 12.5192 \\
$\mathbf{1 9 7 7 - 1 9 9 3}$ & 70.23 & 15 & 0 & $\mathbf{1 2 . 4 5 4 0 7}$ & 12.0761 \\
$\mathbf{1 9 9 4 - 2 0 0 9}$ & 76.788 & 15 & 0 & $\mathbf{1 3 . 3 9 3 2 9}$ & 13.0215 \\
\hline
\end{tabular}

Table 5. The results derived through T test on water-level data series of the watershed in three 15-year spells (through 1966 to 2009).

\begin{tabular}{cccccc}
\hline Periods & $\mathrm{N}$ & Mean & Std. Deviation & $\begin{array}{c}\text { Std. Error } \\
\text { Mean }\end{array}$ \\
\hline $1966-1980$ & 15 & $1.28 \mathrm{E}+03$ & $\mathbf{0 . 8 9 0 8 3}$ & $\mathbf{0 . 2 3 0 0 1}$ & $\mathbf{0 . 2 0 7 8 2}$ \\
$1981-1995$ & 15 & $1.28 \mathrm{E}+03$ & $\mathbf{0 . 8 0 4 8 7}$ & $\mathbf{0 . 5 0 7 4 5}$ & $95 \%$ Confidence Interval of the Difference \\
$1996-2010$ & 15 & $1.27 \mathrm{E}+03$ & $\mathbf{1 . 9 6 5 3 5}$ & Mean & Lower \\
\hline Periods & $\mathrm{t}$ & $\mathrm{df}$ & Sig. (2-tailed) & Difference & 1275.248 \\
\hline $1966-1980$ & $5.55 \mathrm{E}+03$ & 14 & 0 & $\mathbf{1 2 7 5 . 7 4 1 3 3}$ & 1275.6983 \\
$1981-1995$ & $6.14 \mathrm{E}+03$ & 14 & 0 & $\mathbf{1 2 7 6 . 1 4 4}$ & 1276.5897 \\
$1996-2010$ & $2.51 \mathrm{E}+03$ & 14 & 0 & $\mathbf{1 2 7 4 . 1 7 9 3 3}$ & 127091 \\
\hline
\end{tabular}

Table 6. Pearson correlation (top) and spearman correlation (bottom) between water-level with temperature and precipitation.

\begin{tabular}{|c|c|c|c|c|c|c|c|}
\hline & & Water-Level & Water 3 & Rain & 3-Rain & Temp & 3-Tempt \\
\hline \multirow{3}{*}{ Water-Level } & $\begin{array}{c}\text { Pearson } \\
\text { Correlation }\end{array}$ & 1 & $0.956^{* *}$ & 0.073 & 0.098 & $-0.335^{*}$ & -0.251 \\
\hline & Sig. (2-tailed) & & 0 & 0.632 & 0.524 & 0.024 & 0.096 \\
\hline & $\mathrm{N}$ & 45 & 45 & 45 & 45 & 45 & 45 \\
\hline \multirow{4}{*}{$\begin{array}{c}\text { Water-Level } \\
\text { 3-Year } \\
\text { Moving Average }\end{array}$} & $\begin{array}{c}\text { Pearson } \\
\text { Correlation }\end{array}$ & $0.956^{* *}$ & 1 & 0.213 & 0.139 & $-0.476^{* *}$ & $-0.433^{* *}$ \\
\hline & Sig. (2-tailed) & 0 & & 0.16 & 0.362 & 0.001 & 0.003 \\
\hline & $\mathrm{N}$ & 45 & 45 & 45 & 45 & 45 & 45 \\
\hline & & Water-Level & Water 3 & Rain & 3-Rain & Temp & 3-Tempt \\
\hline \multirow{3}{*}{ Water-Level } & $\begin{array}{c}\text { Spearman } \\
\text { Nonparametric } \\
\text { Correlation }\end{array}$ & 1 & $0.900^{* *}$ & 0.004 & 0.117 & $-0.374^{*}$ & -0.198 \\
\hline & Sig. (2-tailed) & . & 0 & 0.98 & 0.443 & 0.011 & 0.192 \\
\hline & $\mathrm{N}$ & 45 & 45 & 45 & 45 & 45 & 45 \\
\hline \multirow{3}{*}{$\begin{array}{c}\text { Water-Level } \\
\text { 3-Year } \\
\text { Moving Average }\end{array}$} & $\begin{array}{c}\text { Spearman } \\
\text { Nonparametric } \\
\text { Correlation }\end{array}$ & $0.900^{* *}$ & 1 & 0.184 & 0.132 & $-0.539^{* *}$ & $-0.407^{* *}$ \\
\hline & Sig. (2-tailed) & 0 & . & 0.227 & 0.386 & $\mathbf{0}$ & 0.006 \\
\hline & $\mathrm{N}$ & 45 & 45 & 45 & 45 & 45 & 45 \\
\hline
\end{tabular}

${ }^{* *}$ Correlation is significant at the 0.01 level (2-tailed). 
Table 7. Out puts obtained through linear regression analysis between water-level of Urmia Lake and the variables.

\begin{tabular}{ccccccccc}
\hline \multirow{2}{*}{ Equation } & \multicolumn{3}{c}{ Model Summary } & \multicolumn{3}{c}{ Parameter Estimates } \\
\cline { 2 - 9 } & R Square & F & df1 & df2 & Sig. & Constant & b1 \\
\hline Linear & $\mathbf{0 . 1 1 2}$ & 5.441 & 1 & 43 & 0.024 & 0.023 & -0.328 \\
\hline
\end{tabular}

The independent variable is temperature. Dependent Variable: water level.

\begin{tabular}{ccccccccc}
\hline \multirow{2}{*}{ Equation } & \multicolumn{3}{c}{ Model Summary } & \multicolumn{3}{c}{ Parameter Estimates } \\
\cline { 2 - 9 } & R Square & F & df1 & df2 & Sig. & Constant & b1 \\
\hline Linear & $\mathbf{0 . 2 2 7}$ & 12.629 & 1 & 43 & 0.001 & -0.001 & -0.477 \\
\hline
\end{tabular}

The independent variable is temperature. Dependent Variable: water-level 3-year moving average.

\begin{tabular}{ccccccccc}
\hline \multirow{2}{*}{ Equation } & \multicolumn{3}{c}{ Model Summary } & \multicolumn{3}{c}{ Parameter Estimates } \\
\cline { 2 - 9 } & R Square & F & df1 & df2 & Sig. & \multicolumn{2}{c}{ Constant } & b1 \\
\hline Linear & $\mathbf{0 . 0 4 5}$ & 2.044 & 1 & 43 & 0.16 & -0.031 & 0.266 \\
\hline
\end{tabular}

The independent variable is precipitation. Dependent Variable: water-level 3-year moving average.

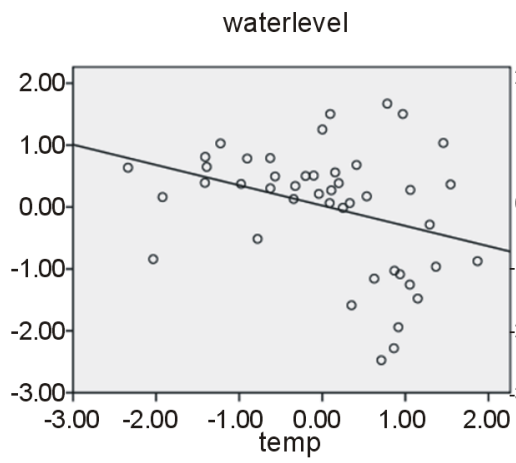

(a) water3

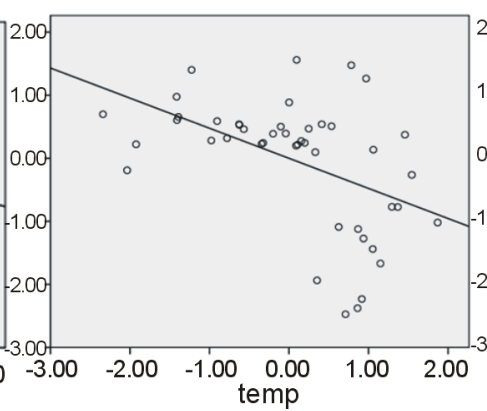

(b) water3

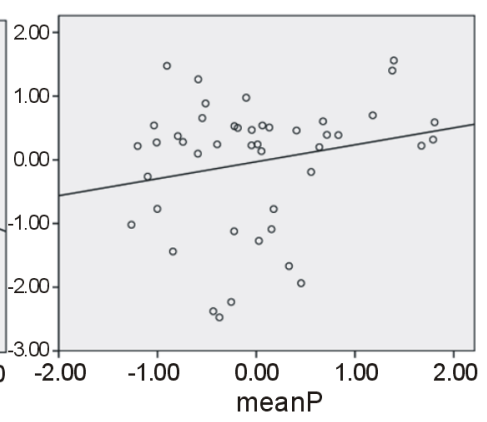

(c)

Figure 7. Linear regression analysis between water-level and temperature (a); water-level 3-year moving average and temperature (b); water-level 3-year moving average and precipitation (c).

Precipitation in general through its produced runoff on the basin, feeds the lake, whiles the runoff extremely has been reserved and controlled by dams and irrigation channels especially through 15 recent years on the Urmia Lake basin. On the contrary, increase of temperature could directly and indirectly affects the water-level of the Lake by raising evaporation as well as water-use rate in agricultural and urban affairs, etc.

Existence of the man-made factors on the basin [Annex] that intensify the water crisis of Urmia Lake could result in a poor consistency between water-level fluctuations of the lake and the changes of meteorological variables (although temperature seems to be more correlated to the water-level, nonetheless the ranks estimated remain always poor). As the low linear correlation estimated ranks don't imply application possibility of prediction scenarios for the lake's water-level behavior based on the precipitation and temperature of the basin.

\section{Conclusions}

During the recent years, water crisis of Urmia Lake is intensified, as from 1998 to the present the water-level of the lake has been slumped persistently below its long term average (1275.35 m). These conditions extremely damaged its valuable ecosystems as well as socio-economic activities of the surrounding areas. Through this investigation, we have found that the meteorological variables on the Urmia Lake basin during 1995 to 2010 show a different behavior, as precipitation's mean value is decreased around $76 \mathrm{~mm}$ (from $336 \mathrm{~mm}$ to $260 \mathrm{~mm}$ ), on the other hand the temperature's mean value increased $1.4^{\circ} \mathrm{C}$ (from $12^{\circ} \mathrm{C}$ to $13.4^{\circ} \mathrm{C}$ ) compared to the previous periods. Nonetheless, reduction of the water-level of the lake, whether in monthly or yearly scales was more harsh and different than the changes of precipitation and temperature. 
Correlation and regression analysis also indicated more significant compatibility between periodic changes of the water-level of Urmia Lake and temperature than the precipitation on its basin. This is because of 1) more chaotic and complicated behavior of the precipitation; and 2) runoff produced by precipitation on the basin extremely is reserved beyond the dams, and disorderly feeds the lake. On the contrary, temperature with a more regular seasonal cycle could significantly affect the water-level of Lake by evaporation and raising the water-use rate on the basin.

The unnatural shrinking of Urmia Lake especially through the recent decade could imply existence of some anthropogenic factors such as: extraordinarily reserving the runoff and construction of dams on the rivers of the basin, over-developing of agriculture and industries on the upstream areas, hyper exploitation of groundwater via deep wells, population growth followed by increase of water use on the basin, construction of a causeway through Urmia Lake that disturbed the normal water cycles of the Lake, etc. [Annex], which could be considered the supplementary causes in recent water crisis of the Lake.

To cope with the current water crisis of Urmia Lake, there could be some management/mitigation plans related to the constructional and natural systems of the basin. One of the imaginable urgent plans in this case, is the finding of the effective synoptic systems with relating to heavy precipitation over the basin in order to recommend the best time for cloud seeding operations, and then extracting the double water perceptible over the basin.

\section{References}

[1] Jahanbakhsh, S., Adalatdost, M. and Tadayoni, M. (2011) Urmia Lake: The Relationship between Sunspots and Climate on the Northwestern of Iran. Geographic Researches Quarterly, 25, 16656-16684.

[2] Mahmoei, H.B., Darvish, M., Fathollahzadeh, H. and Mosayebi, M. (2012) Lake Urmia Water Level Variability, Weather and Climate Change. Proceedings of National Conference on Climate Changes and Its Environmental-Agricultural Impacts. July 2012, Urmia, 727-734.

[3] Shabestari, J.B. (2000) Study of the Water-Level Fluctuations of Urmia LAKE during Quaternary Period. First Congress of Urmia Lake, Iran.

[4] Mohammadi, A., Darvishi, J. and Lak, R. (2010) Study of the Sedimentation History of Urmia Lake Based on the Sedimentary Samples of the Southwestern Bed of the Lake. 29th Congress of Earth Sciences, Iran.

[5] Jalili, S., Morid, S., Banakar, A. and ghanbari, N.R. (2011) Evaluate the Impact of Climate Indices: NAO and SOI, to Water-Level Fluctuations of Urmia Lake through Spectral Analysis Methods. Soil and Water Journal, 25, 140-149.

[6] Eimanifar, A. and Mohebbi, F. (2007) Urmia Lake (Northwest Iran): A Brief Review. Saline Systems, 3, 5.

[7] Reveshty, M.A. and Maruyama, Y. (2010) Study of Uremia Lake Level Fluctuations and Predict Probable Changes Using Multi-Temporal Satellite Images and Ground Truth Data Period (1976-2010) New Challenge about Climate Change or Human Impact. Map Asia 2010, Malaysia.

[8] Rasouly, A.A. (2008) Monitoring the Water-Level Fluctuations of Urmia Lake through Satellite Images Analysis. Proceedings of 3th Conference of Water Resources Management in Iran, Tabriz University, 137-165.

[9] Kebede, S., et al. (2006) Water Balance of Lake Tana and Its Sensitivity to Fluctuations in Rainfall, Blue Nile Basin, Ethiopia. Journal of Hydrology, 316, 233-247. http://dx.doi.org/10.1016/j.jhydrol.2005.05.011

[10] Benduhn, F. and Renard, P. (2004) A Dynamic Model of the Aral Sea Water and Salt Balance. Journal of Marine Systems, 47, 35-50. http://dx.doi.org/10.1016/j.jmarsys.2003.12.007

[11] Beek, T., Voss, F. and Floerke, M. (2010) Modelling the Influence of Irrigation on the Shrinking Aral Sea. Geophysical Research Abstracts, 12, (Page).

[12] Lofgren, B.M., Quinn1, F.H., Clites, A.H., Assel, R.A., Eberhardt, A.J. and Luukkonen, C.L. (2002) Evaluation of Potential Impacts on Great Lakes Water Resources Based on Climate Scenarios of Two GCMs. Journal of Great Lakes Research, 28, 537-554. http://dx.doi.org/10.1016/S0380-1330(02)70604-7

[13] Tabari, M.R. and Ghalehni, M.E. (2012) Evaluation of Urmia Lake’s Water-Need during the Recent Droughts. Proceedings of 9th International Congress of Civil Engineering, Isfahan Technology University, May 2012, 1025-1032.

[14] Takami, G.A. (1993) Urmiah Lake as a Valuable Source of Artemia for Feeding Sturgeon Fry. J Vet Fac Univ Tehran, 47, 2-14.

[15] Takami, G.A. (1987) The Use of Artemia from Ormia Lake (Iran) as Food for Sturgeon. In: Sorgeloos, P., Bengston D.A., Decleir, W., Jaspers, E., Eds., Artemia Research and Its Application Ecology, Culturing, Use in Aquaculture, Wetteren: Universa Press, Wetteren, Belgium, 467-468. 
[16] Van Stappen, G., Fayazi, G. and Sorgeloos, P. (2001) International Study on Artemia LXIII. Field Study of the Artemia urmiana (Günther, 1890) Population in Lake Urmiah, Iran. Hydrobiologia, 466, 133-143. http://dx.doi.org/10.1023/A:1014510730467

[17] Ghaheri, M.H. and Baghal-Vayjooee, N.J. (1999) Lake Urmia, Iran: A Summary Review. International Journal of Salt Lake Research, 8, 19-22. http://dx.doi.org/10.1007/BF02442134

[18] Alipour, S. (2006) Hydrochemistry of Seasonal Variation of Urmia Salt Lake, Iran. Saline Systems, $2,9$. http://dx.doi.org/10.1186/1746-1448-2-9

[19] Kelts, K. and Shahrabi, M. (1986) Holocene Sedimentalogy of Hypersaline Lake Urmia, Northwestern Iran. Paleogeography, Paleoclimatology, Paleoecology, 54, 105-130. http://dx.doi.org/10.1016/0031-0182(86)90120-3

[20] Touloie, J. (1998) Hydrogeochemistry of Urmia Lake. The 1st Oceanology Conference of Iran, Tehran, 20-23.

[21] Street-Perrott, F.A. and Roberts, N. (1983) Fluctuation in Closed-Basin Lakes as an Indicator of Past Atmospheric Circulation Patterns. In: Street-Perrott, F.A., Beran, M. and Ratcliffe, R., Eds., Variation in the Global Water Budget, Reidel, Dordrecht, 331-345.

[22] Jalali, B. (1984) A Report on Urmia Lake. Ministry of Energy, Tehran.

[23] Anon, A. (1987) Study Report on Natural Lakes of Azarbayjan Province. Ministry of Energy, Tehran. 
Scientific Research Publishing (SCIRP) is one of the largest Open Access journal publishers. It is currently publishing more than 200 open access, online, peer-reviewed journals covering a wide range of academic disciplines. SCIRP serves the worldwide academic communities and contributes to the progress and application of science with its publication.

Other selected journals from SCIRP are listed as below. Submit your manuscript to us via either submit@scirp.org or Online Submission Portal.
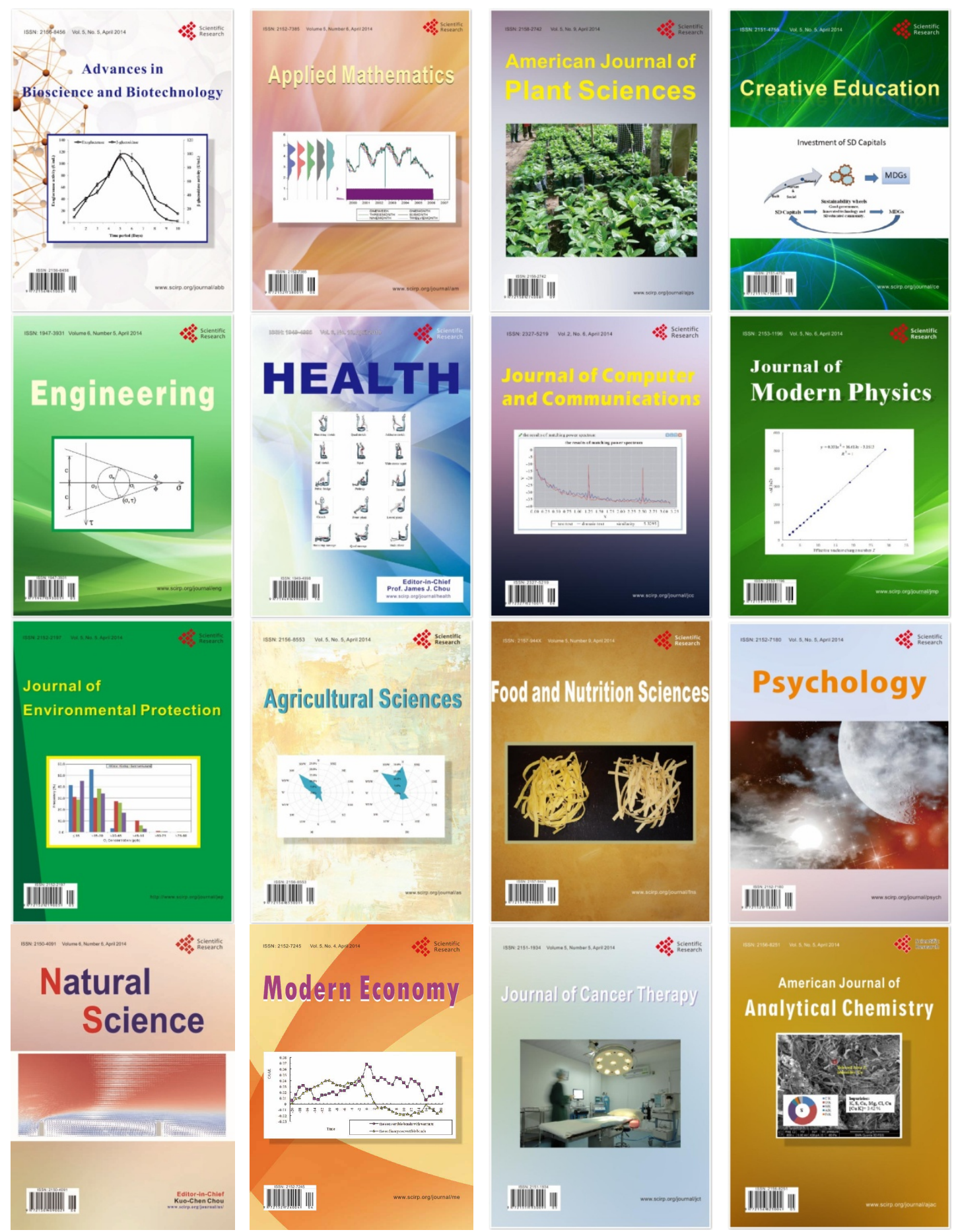